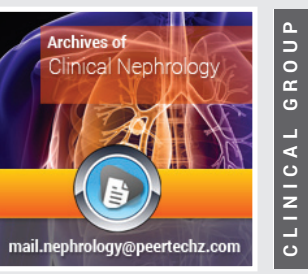

\section{Olea $\mathrm{T}^{1 *}$, Castillo $\mathrm{I}^{2}$, Jiménez $\mathrm{C}^{1}$, Díez $\mathrm{J}^{3}$, Bartolomé $\mathrm{J}^{2}$, Santana $\mathrm{MJ}$, López- Oliva $\mathrm{MO}^{1}$, González $\mathrm{E}^{1}$, Selgas $\mathrm{R}^{1}$ and Carreño V ${ }^{2}$}

'Department of Nephrology, Hospital Universitario La Paz, IdiPAZ. Redinren. Irsin, Spain

2Fundación para el Estudio de Hepatitis Virales e Investigación Biomédica, Spain

${ }^{3}$ Department of Nephrology and Statistics, Hospital Universitario La Paz, IdiPAZ. Redinren. Irsin, Spain

Received: 27 May, 2019

Accepted: 09 July, 2019

Published: 10 July, 2019

*Corresponding author: Olea T, MD, Department of Nephrology, Hospital Universitario La Paz, Paseo de la Castellana 261, 28046- Madrid, Spain, Tel: +34 658158233; E-mail: teresa.olea@salud.madrid.org

Keywords: Kidney transplantation; Occult hepatitis C virus

https://www.peertechz.com

Check for updates

\author{
Research Article
}

\section{Epidemiological and clinical implications in Kidney Transplantation of occult} Hepatitis C virus infection

\section{Abreviations}

ATG: Antitymocite Immunoglobulin; CKD: Chronic Kidney Disease; DGF: Delayed Graft Function; HCV: Hepatitis C virus; HCV: RNA: Hepatitis C virus-Ribonucleic Acid; HIV: Human Immunodeficiency Virus; IMGN: Immune Mediated Glomerulonephritis; KT: Kidney Transplantation; mTOR: Mammalian Target of Rapamycine; NC: Non Coding; NODAT: New Onset Diabetes After Transplantation; OCI: Occult HCV Infection; PBMC: Peripheral Blood Mononuclear Cells; PTLD: Post-Transplant Lymphoproliferative Disease; RT-PCR: Real Time Reverse Transcription;

\section{Introduction}

Chronic hepatitis $\mathrm{C}$ virus (HCV) infection has been recognized as an important health problem in kidney transplant (KT) recipients, with a significantly higher prevalence than in general population [1]. The survival rate for $\mathrm{HCV}$-infected $\mathrm{KT}$ recipients is better than that for HCV-infected hemodialysis patients on transplant waiting lists [2]. However, in KT recipients, HCV infection (often acquired because of dialysis treatment) is associated with liver disease and is an independent risk factor for graft loss, chronic rejection, transplant glomerulopathy, posttransplant diabetes and HCV- associated glomerulonephritis [3]. The increased risk of death in HCV-infected renal allograft recipients has been attributed to cardiovascular mortality, linked someway to the insulin resistance and high risk of new onset diabetes after transplantation (NODAT) rather than the progressive of HCV- related liver disease [4]. Determining the best immunosuppressive regimen after $\mathrm{KT}$ in the presence of HCV infection remains challenging as it has significant consequences on HCV replication and disease [5].

Occult HCV infection (OCI) is characterized by the presence of HCV-RNA in liver or peripheral blood mononuclear cells (PBMC) in the absence of serological markers [6]. OCI may also be diagnosed by concentrating $2 \mathrm{ml}$ of serum by ultracentrifugation followed by HCV-RNA detection by realtime PCR [7]. Our group has found a high prevalence of OCI in hemodialysis patients [8] and also in patients with primary and secondary glomerular nephropathies [9]. In both groups the presence of OCI was associated with a worse outcome including a potential role in the progression of the renal disease. To our knowledge, there is only one study reporting a low prevalence of OCI in KT recipients [10]. Thus, we aimed to determine the prevalence as well as the epidemiological and clinical implications of OCI in a Spanish population of KT recipients. In addition, we also studied the possible association of OCI with renal graft function, development of NODAT and cancer, opportunistic infections, kidney rejection and graft and patient survival 


\section{Material and Methods}

\section{Patients}

This prospective study included 149 patients attending a Nephrology consulting due to functioning KT, at different stages. All patients had to be anti-HCV and serum HCV-RNA negative as well as hepatitis B surface antigen and anti-HIV negative by routine commercial tests. We did not use HCV positive donor as in our center these are reserved for HCV infected recipients.

All patients had to be followed up after KT for a period longer than one year, and their vital prognostic had to be unaffected by any known process. Over 2015 and 2016, 149 adults, non-selected patients, were recruited. The study was approved by the Ethic Committee of the Hospital and was conducted according to the Declaration of Helsinki. Each patient gave a written informed consent and afterwards was tested for OCI. All the participants were followed-up as recommended by the European Best Practice Guidelines for renal transplantation [11]. Recommendations for prevention and treatment about infections, cardiovascular risk (obesity, smoking, hiperlipidaemia NODAT, hypertension) or cancer development (skin, solid organ and PTLD) were strictly followed. A follow-up period of (119.8 \pm 77 months) was used to explore kidney function stability, needs of immunosuppression and the incidence of complications related with KT outcome. The last 24 months of this follow-up allowed the observation of all patients after OCI testing to explore its role on graft and patient survival.

Type and time on dialysis, previous blood transfusions, surgical procedures, household contacts and partners diagnosed of HCV infection, as the presence of tattoo or piercing were recorded as potential risk factors for HCV infection. The acute and chronic rejection had to be confirmed by a kidney graft biopsy. The delayed graft function (DGF) was defined as the need for dialysis the first week post-KT. The presence of NODAT was defined as the requirement of oral antidiabetics or insulin for a minimum period of 30 days post-KT. Opportunistic infections were registered in $\mathrm{KT}$ recipients, as well as infections due to organisms with microbiological resistance. The time until the loss of the graft was calculated from the date of the KT until the date of graft loss. The patient's survival was calculated from the KT until the date of death.

\section{Methods}

HCV- RNA detection in PBMC and in plasma samples: PBMC and plasma were isolated from anticoagulated blood by Biocoll (Biochrom, Berlin, Germany) density gradient centrifugation. Plasma was aliquoted and stored at $-30^{\circ} \mathrm{C}$. PBMC were washed three times in phosphate-buffered saline and stored in RNAlater solution (Ambion, Austin, TX) at $-30^{\circ} \mathrm{C}$.

Total RNA from PBMC was isolated with SV Total RNA Isolation System (Promega, Madison, WI). After precipitation, pellets were dissolved in diethyl-pyrocarbonate-treated water and RNA concentration was determined by spectrophotometry. In addition, $2 \mathrm{ml}$ of plasma were ultracentrifuged over a $10 \%$ sucrose cushion at $100,000 \mathrm{xg}$ for $17 \mathrm{~h}$ at $4^{\circ} \mathrm{C}$. The pellet was dissolved in $250 \mathrm{ml}$ of TE buffer (Tris- $\mathrm{HCl} 10 \mathrm{mmol} / \mathrm{l}$, EDTA $10 \mathrm{mmol} / \mathrm{l} ; \mathrm{pH}$ 7.5) and, total RNA was isolated with Trizol LS Reagent (Invitrogen, Carlsbad, CA.), precipitated, and the pellet dissolved in diethyl-pyrocarbonate-treated water.

Amplification of the HCV-RNA 5' noncoding (NC) region was performed by quantitative real-time reverse transcription (RT)-PCR with fluorescence resonance energy transfer probes. Two microliters of total RNA isolated from $2 \mathrm{ml}$ of ultracentrifuged plasma, or $0.5 \mu \mathrm{g}$ of total RNA from PBMC were retrotranscribed and amplified in a single tube reaction containing RNA reaction mix (LightCycler Master Hybprobe, Roche Diagnostics, Mannheim, Germany), The conditions of this RT-PCR have been previously described [12-16]. A standard curve constructed with 10 -fold dilutions of a synthetic HCVRNA was used for quantification. The lower limit of HCV-RNA detection of the assay was $10 \mathrm{IU} / \mathrm{ml}$ (mean threshold cycle [Ct], 39.32) with a lower limit of quantification of $100 \mathrm{IU} / \mathrm{ml}$ (mean $\mathrm{Ct}, 35.64$ ), as determined by testing serial dilutions of HCVRNA positive serum sample, in which HCV-RNA quantification was previously assessed by an HCV test (Cobas TaqMan, Roche Diagnostics).

HCV-RNA detection was performed by laboratory personnel who were blinded to the clinical status of the patients. Each PCR run included a maximum number of 10 samples along with negative controls (repeatedly HCV-RNA negative sera and PBMC samples) and reagent blanks in which total RNA was replaced with PCR-grade water. Negative controls and blanks were processed with the samples and accompanied them through the entire PCR process. As positive controls, HCVRNA positive sera and PBMC from patients with chronic HCV infection were used. The guidelines of Kwok and Higuchi [12], were strictly observed for avoiding contaminations. To further confirm OCI results, positive samples and randomly selected negative ones were tested again on different days by another person who was blinded to previous results.

\section{Statistical analysis}

The data were processed by a database in the program SPSS version 20, for its statistical treatment. For the description of continuous quantitative variables, the mean was used together with the standard deviation. Qualitative variables were described by absolute and relative frequencies expressed as a percentage. The comparisons between continuous quantitative variables between the two independent groups were performed primarily using a non-parametric (Mann-Whitney U Test) technique. For the analysis of frequencies between qualitative variables, the chi-square test or Fisher's exact test was used when possible. The analysis of the temporal evolution between moments of the quantitative variables was performed in paired form, by the Wilcoxon signed rank test. A KaplanMeier method and log-rank test were used to calculate kidney graft and patient survival. A $P$ value $<0.05$ indicated statistical significance. 


\section{Results}

Of the $149 \mathrm{KT}$ receptors studied, 20 tested positive for the presence of HCV RNA in PBMC with an average concentration of 1727.35 copies per $\mu \mathrm{g}$ of total RNA (range 347-6810). HCV RNA was detected in the plasma after the ultracentrifugation of $2 \mathrm{ml}$ of plasma in another patient at a concentration of 872 copies per $\mathrm{ml}$ of plasma. Positive results were obtained in different runs on different days, excluding intersample cross-contamination and the retesting of positive and negative samples in a blind fashion by different operators, confirmed the results. Therefore, we found a prevalence of occult HCV infection of $21 / 149(14.1 \%)$; these patients had viral RNA detectable in PBMC or in plasma after ultracentrifugation despite the absence of anti-HCV antibodies.

When comparing demographic and clinical features (12 months after KT) of the patients according to their OCI status (Table 1) it was found that previous history of blood transfusion was significantly higher $(\mathrm{p}=0.044)$ in the OCI group $(18 ; 94.7 \%)$ than in the negative one $(91 ; 71.7 \%$ ), (odds ratio $=7.121 ; 95 \%$ confidence interval: 0.916-55.332).

At this first year of post KT follow-up, renal function and proteinuria were similar in both groups although plasma creatinine and proteinuria in the OCI positive group were mildly lower $(1.44 \pm 0.86(\mathrm{mg} / \mathrm{dl}) ; 0.30 \pm 0.30(\mathrm{~g} / 24 \mathrm{~h}))$ than in the OCI negative group $(1.58 \pm 0.49(\mathrm{mg} / \mathrm{dl}) ; 0.42 \pm 0.65$ $(\mathrm{g} / 24 \mathrm{~h}))$. However, at the end of the whole follow-up period (119.8 \pm 77 months), renal function tended to decline faster and proteinuria values were higher in the OCI positive group (1.93 $\pm 1.05(\mathrm{mg} / \mathrm{dl}) ; 0.86 \pm 1.14(\mathrm{~g} / 24 \mathrm{~h}))$, than in the OCI negative group, $(1.74 \pm 0.80(\mathrm{mg} / \mathrm{dl}) ; 0.62 \pm 1.38(\mathrm{~g} / 24 \mathrm{~h}))$, although these differences did not reach statistical significance $(p=0.44$ and 0.77).

Type of immunosuppression at induction therapy and once stabilized at the time of the study, did not differ between OCI positive and negative group (Table 2 ).

Clinical complications post-KT were similar in both group of patients (Table 3).

Graft loss occurred in 5/149 (3.3\%) patients, being 2 of them OCI positive (Table 2$)$. In 3 of these 5 patients $(60 \%)$, transplant glomerulopathy was the cause of returning to dialysis programme (one patient was OCI positive). In the remaining 2 cases, it was due to development of myeloma multiple (patient with OCI) and pelvic cancer (OCI negative). During the follow-up, it was recorded a total of $7 / 149(4.7 \%)$ exitus. In the group of patients with OCI there was a trend of more deaths $(3 / 21 ; 14.3 \%)$ than in negative ones $(4 / 128 ; 3.1 \%)$ but without statistical difference $(\mathrm{p}=0.06)$ (Table 3$)$. In the

Table 1: Demographic, epidemiological, clinical and analytical parameters of the patients at the study.

\begin{tabular}{|c|c|c|c|c|c|}
\hline & Occult negative HCV infection & Occult positive HCV infection & Significance & Odds ratio & 95\% Confidence \\
\hline & $(N=128)$ & $(\mathrm{N}=21)$ & & & interval \\
\hline Age (years; mean \pm SD) & $52.73 \pm 14.43$ & $55.19 \pm 14.03$ & 0.386 & & \\
\hline Male (n; \%) & $83 ; 64.8$ & $12 ; 57.1$ & 0.625 & 0.723 & $0.283-1.845$ \\
\hline Time on dialysis programme (months; mean $\pm \mathrm{SD}$ ) & $31.10 \pm 21.13$ & $25,55 \pm 18,97$ & 0.585 & & \\
\hline $\begin{array}{l}\text { Time of follow up after renal transplantation (months; mean } \\
\qquad \pm S D)\end{array}$ & $120 \pm 78.56$ & $118.52 \pm 68.6$ & 0.475 & & \\
\hline Serum creatinine $(\mathrm{mg} / \mathrm{dl}$; mean $\pm \mathrm{SD})$ & $1.58 \pm 0.49$ & $1.44 \pm 0.86$ & 0.096 & & \\
\hline Proteinuria (gr/24h; mean \pm SD) & $0.42 \pm 0.65$ & $0.30 \pm 0.30$ & 0.247 & & \\
\hline \multicolumn{6}{|l|}{ Risk factors for HCV infection: (n;\%) } \\
\hline Type of dialysis & & & 0.520 & N/A & N/A \\
\hline Hemodialysis & $52 ; 43.7$ & $10 ; 55.6$ & & & \\
\hline Peritoneal dialysis & $44 ; 37$ & $6 ; 33$ & & & \\
\hline None & $3 ; 2.5$ & $0 ; 0$ & & & \\
\hline Both & $20 ; 16.8$ & $2 ; 11.1$ & & & \\
\hline Previous Blood Transfusion & $91 ; 71.7$ & $18 ; 94.7$ & 0.044 & 7,127 & $0.916-55332$ \\
\hline Household HCV contact & $0 ; 0$ & $0 ; 0$ & 0 & N/A & N/A \\
\hline Tatoo/drogadiction & $11 ; 12.8$ & $4 ; 25$ & 0.247 & 2,273 & $0.622-8.310$ \\
\hline HBV infection & $19 ; 15.7$ & $5 ; 27.8$ & 0.199 & 2,065 & $0.659-6.467$ \\
\hline Etiology of renal disease $(n ; \%)$ & & & 0.081 & N/A & N/A \\
\hline Glomerular nephropathy & $37 ; 29.8$ & $1 ; 4.8$ & & & \\
\hline Hereditary nephropathy & $35 ; 28.2$ & $4 ; 19$ & & & \\
\hline Systemic nephropathy & $14 ; 11.3$ & $5 ; 23.8$ & & & \\
\hline Tubulointersticial nephropathy & $22 ; 17.7$ & $5 ; 23.8$ & & & \\
\hline Diabetic nephropathy & $16 ; 12.9$ & $6 ; 28.6$ & & & \\
\hline
\end{tabular}


OCI positive group deaths were due to urinary tract cancer, myeloma, and one of sudden death, while in the OCI negative group causes were urinary tract neoplasia, cervix and lung cancer and septicaemia. Therefore, neoplasia was the first cause of death in both groups.

With respect to the outcome of renal transplantation, in terms of graft and patient survival at $(9.98 \pm 6.41$ years) (Figure 1), it was found that OCI patients had significant greater loss of

Table 2: Immunosuppression according to occult HCV infection.

\begin{tabular}{|c|c|c|c|c|c|}
\hline & $\begin{array}{c}\text { Occult negative } \\
\text { HCV infection }\end{array}$ & $\begin{array}{c}\text { Occult } \\
\text { positive } \\
\text { HCV } \\
\text { infection }\end{array}$ & Significance & $\begin{array}{c}\text { Odds } \\
\text { ratio }\end{array}$ & $\begin{array}{c}95 \% \\
\text { Confidence }\end{array}$ \\
\hline Mycophenolate & (n=129) & & & interval \\
\hline mofetil (n; \%) & $99 ; 79,2$ & $18 ; 85.7$ & 0.767 & 1,576 & $0.431-5.761$ \\
\hline mTOR (n; \%) & $22 ; 17.6$ & $2 ; 9.5$ & 0.529 & 0.493 & $0.107-2.271$ \\
\hline ATG (n; \%) & $42 ; 49.4$ & $7 ; 46.7$ & 1 & 0.896 & $0.298-2.691$ \\
\hline Basiliximab (n; \%) & $28 ; 32.9$ & $6 ; 40$ & 0.572 & 1,357 & $0.439-4.192$ \\
\hline $\begin{array}{c}\text { Calcineurinic } \\
\text { inhibitor (n; \%) }\end{array}$ & $94,75.2$ & $17 ; 81$ & & N/A & N/A \\
\hline Tacrolimus & $17 ; 13,6$ & $2 ; 9.5$ & & & \\
\hline Cyclosporin & $14 ; 11,2$ & $2 ; 9.5$ & & & \\
\hline None & $89 ; 1.8$ & $14 ; 66.7$ & 0.613 & 0.787 & $0.293-2.112$ \\
\hline
\end{tabular}

HCV: Hepatitis C virus; mTOR: mammalian Target of Rapamycine; ATG: antitymocite immunoglobulin; N/A: Not available.

Table 3: Clinical complications post renal transplantation according to negative/ positive occult HCV infection.

\begin{tabular}{|c|c|c|c|c|c|}
\hline & $\begin{array}{l}\text { Occult } \\
\text { negative HCV }\end{array}$ & \begin{tabular}{|l|} 
Occult \\
positive HCV
\end{tabular} & Significance & $\begin{array}{l}\text { Odds } \\
\text { ratio }\end{array}$ & $\begin{array}{l}95 \% \\
\text { Confidence }\end{array}$ \\
\hline & $\begin{array}{l}\text { infection } \\
(n=128)\end{array}$ & $\begin{array}{l}\text { infection } \\
(n=21)\end{array}$ & & & interval \\
\hline DGF (n; \%) & $17 ; 13.5$ & $2 ; 9.5$ & 1 & 0.675 & $0.144-3.161$ \\
\hline $\begin{array}{l}\text { Acute rejection } \\
(\mathrm{n} ; \%)\end{array}$ & $13 ; 10.3$ & $2 ; 9.5$ & 0.603 & N/A & N/A \\
\hline $\begin{array}{l}\text { Opportunistic } \\
\text { infection (n;\%) }\end{array}$ & $46 ; 36.5$ & $7 ; 33.3$ & 1 & 0.870 & $0.327-2.310$ \\
\hline NODAT (n; \%) & $29 ; 22.65$ & $6 ; 28.57$ & 0.384 & 2,129 & $0.834-5.433$ \\
\hline Cancer (n;\%) & $24 ; 18.9$ & 7; 33.3 & 0.151 & 2,146 & $0.781-5.893$ \\
\hline $\begin{array}{l}\text { Chronic } \\
\text { rejection (n; \%) }\end{array}$ & $5 ; 3.9$ & $2 ; 9.5$ & 0.257 & 2,589 & $0.469-14.310$ \\
\hline $\begin{array}{l}\text { Myocardial } \\
\text { infartion (n;\%) }\end{array}$ & $14 ; 11$ & $4 ; 19$ & 0.289 & 1,899 & $0.559-6.449$ \\
\hline $\begin{array}{l}\text { Cerebrovascular } \\
\text { ischemia }(n ; \%)\end{array}$ & $4 ; 3.1$ & $1 ; 4.8$ & 0.540 & 1,538 & $0.163-14.467$ \\
\hline Graft loss (n;\%) & $3 ; 2.4$ & $2 ; 9.5$ & 0.147 & 4,351 & $0.682-27.760$ \\
\hline Deaths (n;\%) & $4 ; 3.1$ & $3 ; 14.3$ & 0.06 & 5,125 & $1.059-24.796$ \\
\hline
\end{tabular}

Acute and chronic rejection had to be confirmed by a renal allograft biopsy. Delayed graft function (DGF) was defined as need of dialysis. New-onset diabetes after transplantation (NODAT) was defined as the requirement of oral antidiabetics or insulin for a minimum period post-KT (often 30 days). Common infections in solid organ transplant recipients as well as infections due to organisms with microbiological resistance were recorded.

N/A: Not available.

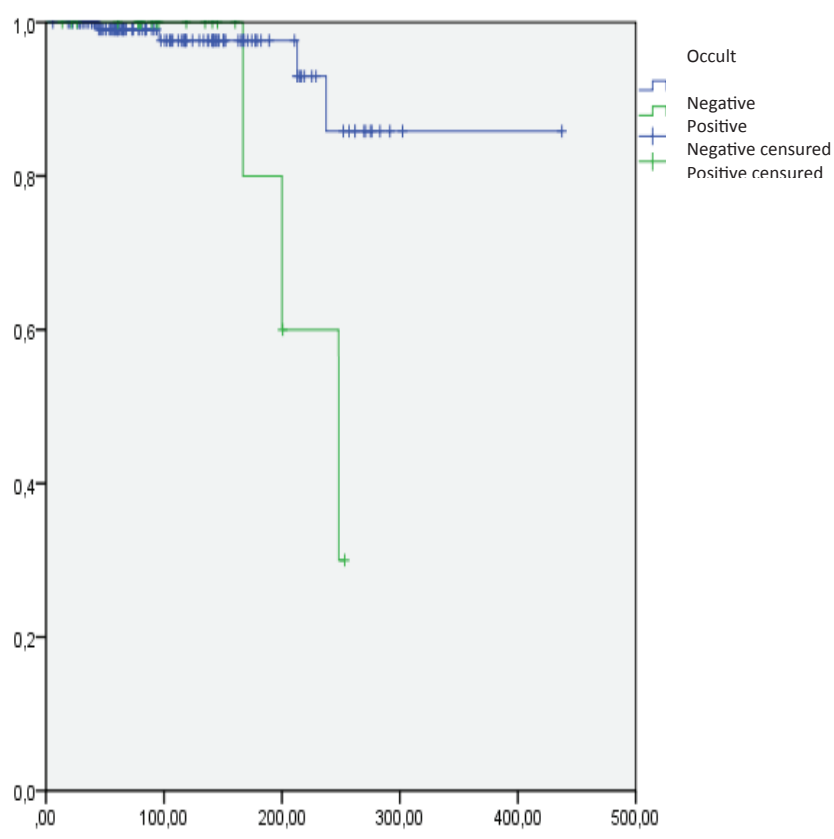

Time to allograft loss was calculated from KT until the date of allograft loss. $\mathrm{OCl}$ positive patients had significant greater loss of the graft $(2 ; 9.5 \%)$ vs $\mathrm{OCl} \mathrm{OO}$ negative ones $(3 ; 2.4 \%)$, $\mathrm{p}=0.02$.

Figure 1A: Kaplan-Meier plot for Graft survival according to $\mathrm{OCl}$ recipients. (Months).

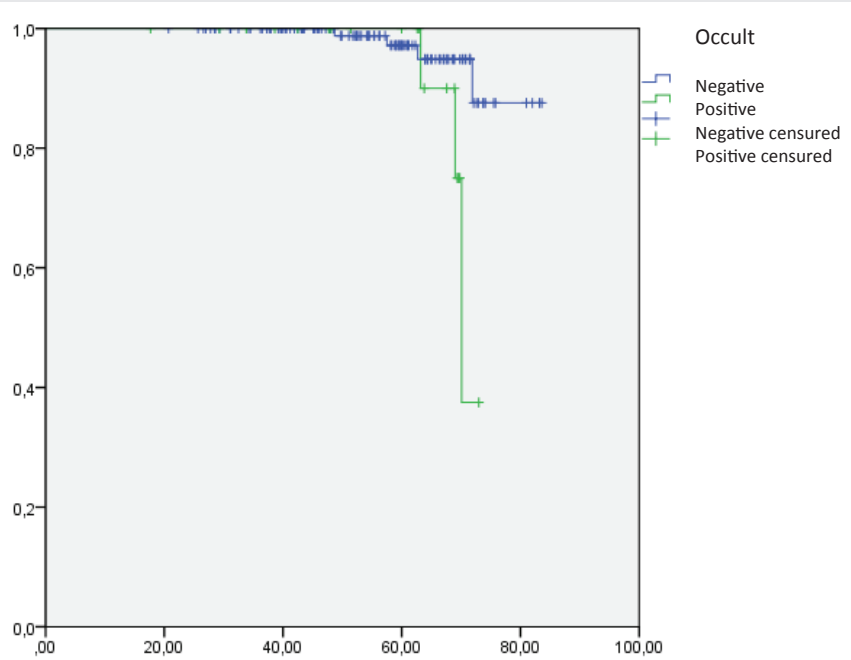

The patient's survival was calculated from the KT until the date of death

OCl positive patients had significant less survival $(3 ; 14,3 \%$ deaths) than negative ones $(4 ; 3,1 \%), p=0.04$

Figure 1B: Kaplan-Meier plot for patient survival according to $\mathrm{OCI}$ recipients (Years).

the graft $(2 ; 9.5 \%)(\mathrm{p}=0.02)$ and patient $(3 ; 14.3 \%)(\mathrm{p}=0.04$, than negative ones $(3 ; 2.4 \%$ vs $4 ; 3.1 \%)$ respectively.

There was a recipient in the OCI negative group with an extremely long-term graft survival (432 moths). Statistical analysis was repeated excluding this patient and statistical significances were still confirmed $(\mathrm{p}=0.02$ and $\mathrm{p}=0.04)$. 


\section{Discussion}

The prevalence of positive occult HCV in patients with KT in our study was $14.1 \%$, as evidenced by the detection of HCV RNA in PBMC or plasma after a lower ultracentrifugation than that found in patients on hemodialysis (45\%) and IMGN (38\%) and more than in patients with diabetic nephropathy $(8 \%)$ $[8,9,13]$. The prevalence of HCV infection in KT is quite variable depending on the geographical areas. One study reported a progressive and marked decrease in the prevalence of HCV infection among kidney transplant recipients in Spain from $29.5 \%$ in 1990 to $10 \%$ in 1998 [15].

Baid and Agrawal [10], found a low prevalence of positive occult HCV infection $2 / 398(0.5 \%)$ in patients with KT. They performed a 30-month longitudinal follow-up of the 3 patients with occult HCV infection, and there was no clinical or virological evidence of HCV infection. This contrasts with our results in which we observed worse outcome of renal function, perhaps due to a longer follow-up period.

The difference found in the prevalence of occult HCV in both studies can be explained by the difference in prevalence of HCV in the general population in Spain ( $2 \%$ ) and in Germany $(0.3 \%)$.

In the retrospective Spanish epidemiological study (GEHEP) of HCV, which covered the period 2000-2015, the most frequent route of transmission among 10,441 patients for whom data were available was parenteral $(58.7 \%)$, followed by unknown origin $(38,6 \%)$ and sexually transmitted [16]. According to this study, we found that prior blood transfusion was the main risk factor for the acquisition of positive occult HCV. In this sense, occult HCV infection has been described in progress among $50 \%$ of the blood donors who tested positive for the HCV corespecific antibody and were negative for anti-HCV and HCV RNA in routine screening in a study of forty two donations $(2.1 \%)$ [16] (The study was in 2007 blood donors negative for anti HCV and HCV RNA in routine screening, of which $\mathbf{4 2}$ were positive for anti-HCV. Three of these 42 donors $(7.1 \%)$ had occult HCV infection. In another recent study in China that included blood samples from blood donors that were anti-HCV negative and in which it was determined in PBMC, a prevalence of $2.2 \%$ was found [17].

The effect of HCV infection on the risk of acute rejection is controversial [7]. It has been reported that the rate of acute rejection in patients with HCV infection is $14.5 \%$ over a 20 -year period [18]. Immunosuppressive drugs have various effects on viremia. [19-21]. We did not identify statistical differences between both groups in immunosuppression strategies in graft survival or of the patient, and the neoplasm in the positive occult HCV group was related to $\mathrm{CKD}$, and not to immunosuppressive medication [22].

Recipients of organ transplants with an existing active HCV infection have a higher frequency of life-threatening infections after surgery compared to recipients without HCV infection $[14,22]$. We did not find differences in the two groups according to the result of the occult HCV infection.
In KT, NODAT is an important cause of post-transplant morbidity and mortality [23]. The incidence is quite variable according to its definition, which varies between $2 \%$ and $53 \%$. The prevalence of NODAT has increased $[24,25]$. The cause is multifactorial and infection by HCV has been implicated in the pathogenesis. We did not find differences in the immunosuppression administered between the two groups, but the positive occult HCV infection tended to have more NODAT. KT recipients with HCV have a reduced chance of survival compared to transplant recipients without HCV infection. The mortality rate at HCV positive receptors was approximately 3 times higher than that of non-infected recipients (12; $1 \%$ versus $3.7 \%$ ) [3]. The increased risk of death in renal allograft recipients infected with HCV has been attributed to cardiovascular mortality. We also did not find differences in cardiovascular events (myocardial infartion or cerebrovascular ischemia) and neoplasia was the first cause of death in our study.

In the positive occult HCV group deaths were due to cancer of the urinary tract and myeloma, related to CKD, and in urinary tract neoplasms of occult negative HCV group, cancer of the cervix, related to CKD and lung cancer related to immunodeficiency, according to Stewart et al [22] and septicemia. In our group, the 5-year survival rate of patients is $90 \%$ and so, the number of not included dead patients is limited and in no case their cause of death was due to a liver problem.

We did not have any hepatocellular carcinoma. Posttransplant lymphoproliferative disorder and multiple myeloma have been associated with HCV infection $[26,27]$, and we have also found a high prevalence of monoclonal gammopathy in diabetic nephropathy patients with positive occult HCV patients [14]. In a recent meta-analysis by Yuying Li, HCV increased the risk of multiple myeloma in countries with a high prevalence of HCV [28]. It has been also reported by Hashem A. et al a prevalence of $24,5 \%$ of OCI in patients diagnosed of multiple myeloma compared to a $3 \%$ OCI in a control group $(\mathrm{p}=0.01)$ suggesting association of $\mathrm{OCI}$ and multiple myeloma [29]. Besides, Farahani M. et al have also detected a prevalence of $1.9 \%$ of OCI in patients who suffer lymphoproliferative disorders [30].

\section{Limitations of the study}

Given the difficulty in recruiting patients for this study, this study can present statistical power problems due to a limited sample size especially when there is stratification. For example, in the comparison between positive and negative OCI and presence of cancer we have a power of $25.5 \%$ or a beta error of $74.4 \%$. In another study [10], the prevalence of the occult hepatitis $\mathrm{C}$ virus was low, which corroborates the difficulty in recruiting a sufficient sample size. For all these reasons, we believe that the difficulty in obtaining a sufficiently powerful study in this field should be taken into account.

In conclusion, in patients with $\mathrm{KT}$ there is a lower prevalence (14.1\%) of occult positive HCV compared to the prevalence in patients with immune -mediated glomerulonephritis (39\%) or hemodialysis $(45 \%)$. Blood transfusion prior to KT was the 
main risk factor for acquiring occult HCV infection. The longterm survival of the graft and patients of OCI positive receptors were diminished compared to that of OCI negative receptors, although the contribution of particular comorbidities did not reach statistical significance. In the group with positive occult $\mathrm{HCV}$, however, the progression of kidney disease tended to be faster. We did not identify statistical differences between both groups in immunosuppressive strategies and it seems not to affect OCI.

\section{Acknowledgements}

\section{ISCIII RETIC REDINREN RD16/0009 FEDER FUNDS}

\section{GRANT MUTUA MADRILEÑA.}

\section{GRANT FROM GIOVANNI RANDI S.P.A. (Italy)}

\section{References}

1. Pereira BJ, Levey A (1997) Hepatitis C virus infection in dialysis and rena transplantation. Kidney Int 52: 981-999. Link: http://bit.ly/2JqYX8U

2. Ozer Etik D, Ocal S, Boyacioglu AS (2015) Hepatitis $C$ infection in hemodialysis patients: A review. World J Hepatol 7: 885-895. Link: http://bit.ly/2G2uA8e

3. Kidney Disease (2008) Improving Global Outcomes (KDIGO). KDIGO clinica practice guidelines for the prevention, evaluation and treatment of hepatitis $\mathrm{C}$ in Chronic kidney Disease. Kidney Int 73: S1-S99.

4. Morales JM (2012) Impact of Extrahepatic Complications (diabetes and Glomerulonephritis) Associated with Hepatitis C Virus Infection after Renal Transplantation. Hepatitis $C$ in Renal Disease, Hemodialysis and Transplantation. Contrib Nephrol Basel Karger 176: 108-116. Link: http://bit.ly/2LdujmM

5. Morales JM (2012) Hepatitis C in Renal Disease, Hemodialysis and Transplantation. Contrib Nephrol Basel Karger 176: 97-107. Link: http://bit.ly/2Jr0b40

6. Carreño V (2014) Seronegative occult hepatitis C virus infection: clinical implications. J Clin Virol 61: 315-320. Link: http://bit.ly/2YHGtYn

7. Bartolome J, López-Alcorocho, Castillo I (2007) Ultracentrifugation of serum samples allows detection of hepatitis $\mathrm{c}$ virus RNA in patients with hepatitis $\mathrm{C}$ virus. J Virol 81: 7710-7715. Link: http://bit.ly/2NJYjZF

8. Barril G, Castillo I, Carreño V (2008) Occult Hepatitis C Virus Infection among Hemodialysis Patients. J Am Soc Nephrol 19: 2288-2292. Link: http://bit.ly/30n7BfB

9. Castillo I, Martínez-Ara JA, Olea T, Bartolome J, Madero R, et al. (2014) High prevalence of occult hepatitis $C$ virus infection in patients with primary and secondary glomerular nephropathies. Kidney Int 86: 619-624. Link: http://bit.ly/2YKHL4W

10. Baid-Agrawal S, Schindler R, Reinke P, Staedtler A, Rimpler S, et al. (2014) Prevalence of occult hepatitis $\mathrm{C}$ infection in chronic hemodialysis and kidney transplant patients. J Hepatol 60: 928-933. Link: http://bit.ly/2Xwa7Dk

11. EBPG Expert Group on Renal Transplantation (2002) European best practice guidelines for renal transplantation. Nephrol Dial Transplant. 17: 50-55. Link: http://bit.ly/2S3kClp

12. Quiroga JA, Avellón A, Bartolomé J, Andréu M, Flores E, et al. (2016) Detection of hepatitis $\mathrm{C}$ virus (HCV) core-specific antibody suggests occult HCV infection among blood donors. Transfusion 56: 1883-1890. Link: http://bit.ly/32bSTtL
13. Kwok S, Higuchi R (1989) Avoiding false positive with PCR. Nature 339: 237238. Link: http://bit.ly/2XGeZBe

14. Olea T, Castillo I, González E (2016) Occult Hepatitis C Virus Infection in Patients with Diabetic Nephropathy: Epidemiological and Clinical Implications. WJRR 3: 65-69. Link: http://bit.ly/2YEAvYa

15. Morales JM, Fabrizi F (2015) Hepatitis C and its impact on renal transplantation. Nat Rev Nephrol 11: 172-182. Link: http://bit.ly/2XC26wL

16. Aguilera A, D Navarro, F Rodriguez-Frias (2017) Prevalence and distribution of hepatitis $C$ virus genotypes of hepatits $C$ virus genotypes in Spain during 2000-2015 period (the GEHEP 005 study). J Viral Hepat 24: 725-732. Link: http://bit.ly/2NGqIQp

17. Lin $\mathrm{H}$, Chen $\mathrm{X}$, Zhu S (2016) Prevalence of occult hepatitis $\mathrm{C}$ virus infection among blood donors in Jiangsu, China. Intervirology 59: 204-210. Link: http://bit.ly/2Ld3DTp

18. Roth D, Gaynor JJ, Reddy KR (2011) Efffect of kidney transplantation on outcomes among patients with hepatitis C. J Am Soc Nephrol 22: 1152-1160. Link: http://bit.ly/32dLz0C

19. Wathashi K (2003) Ciclosporin A suppresses replication of hepatitis C virus genome in cultured hepatocytes. Hepatology 38: 1282-1288. Link: http://bit.ly/2JoPjoD

20. Berenguer M, Rayuela A, Zamora J (2007) Immunosuppression with calcineurin inhibitors with respect to the outcome of HCV recurrence after liver transplantation: results of a meta-analysis. Liver Transpl 13: 21-29. Link: http://bit.ly/2G1M44m

21. Oriol M, Baid Agrawal S, Moradpour D (2012) Immunosuppression in Hepatitis C Virus Infected Patients after Kidney Transplantation. Contrib Nephrol 176 97-107. Link: http://bit.ly/32fgbij

22. Stewart JH, Vajdic CM, van Leeuwen MT (2009) The pattern of excess cancer in dialysis and transplantation. Nephrol Dial Transpl 24: 3225-3231. Link: http://bit.ly/32jE1 cy

23. Scott DR, Wong JK, Spicer TS, Dent H, Mensah FK, et al. (2010) Adverse impact of hepatitis $\mathrm{c}$ virus infection on renal replacement therapy and renal transplant patients in Australia and New Zeland. Transplantation 90: 1165 1171. Link: http://bit.ly/2Lats6x

24. Sneha Palepu, Ramesh Prasad GV (2015) New onset diabetes mellitus after kidney transplantation: Current status and future directions. World $J$ Diabetes 6: 445-455. Link: http://bit.ly/2Xx3aNy

25. Muscogiuri G, De Rosa P (2012) New-onset diabetes after kidney transplantation: prevalence, risk factors, and management. Transplantation 93: 1189-1195. Link: http://bit.ly/2Xx4EY8

26. Caillard S, Porcher R, Provot F, Moulin B; French PTLD Working Group (2006) Post-transplant lymphoproliferative disorders occurring after renal transplantation in adults: report of 230 cases from the French Registry. Am J Transplant 6: 2735-2742. Link: http://bit.ly/2G2rhxG

27. Caillard S, Lamy FX, Quelen C (2006) Myeloma, Hodgkin disease and lymphoid leukaemia after renal transplantation: Characteristics, risk factors and prognosis. Transplantation 27: 888-895. Link: http://bit.ly/2xCw4Bh

28. Li Y, Li Y, Zhang L (2017) Hepatitis C virus infection and risk of multiple myeloma: Evidence from a meta-analysis based on 17 case-control studies. J Viral Hepatol 24: 1151-1158. Link: http://bit.ly/2xB7elj

29. Farahani M, Bokharaei-Salim F, Ghane M, Basi A, Meysami $P$, et al (2013) Prevalence of occult hepatitis C virus infection in Iranian patients with lymphoproliferative disorders. J Med Virol 85: 235-240. Link: http://bit.ly/2JKQ4rh

30. Hashem A, Fahmy H, Abdo A (2015) Prevalence of Occult Hepatitis C Virus Infection in Patients with Multiple Myeloma. Med J Cairo Univ 83: 507-513. Link: http://bit.ly/2LixgCX

Copyright: (c) 2019 Olea T, et al. This is an open-access article distributed under the terms of the Creative Commons Attribution License, which permits unrestricted use, distribution, and reproduction in any medium, provided the original author and source are credited. 